\title{
Experiences of Middle School Students Following a Financial Literacy Simulation
}

\author{
Joanne C. Caniglia \\ School of Teaching, Learning and Curriculum Studies, Kent State University \\ 150 Terrace Drive, Kent, OH 44240. \\ E-mail: jcanigl1@kent.edu \\ Davison M. Mupinga* \\ School of Teaching, Learning and Curriculum Studies, Kent State University \\ 150 Terrace Drive, Kent, OH 44240. \\ E-mail: dmupinga@kent.edu
}

\begin{abstract}
The need for today's youth to acquire financial literacy skills cannot be taken lightly as this knowledge leads to better financial decisions. However, there is a shortage of qualified teachers to teach financial skills. When teachers are not available, one way to provide students with such skills is through simulations. This article describes the experiences of middle school students' following the Reality Store ${ }^{\circledR}$, a financial simulation. The activity, divided into 15 different stations, provided hands-on experiences and opportunities for students to think about their futures and career choices in relation to their economic well-being. One hundred fifty-six (156) eighth grade students participated in the simulation activity. Results from the activity indicated students: 1) overwhelmingly enjoyed the experience; 2) lacked knowledge of careers and the educational requirements necessary to achieve their desired life choices; and 3) liked the opportunity to make "life" decisions. Suggestions for teaching financial literacy and career awareness using simulations are provided.
\end{abstract}

Keywords: Career awareness, Experiential education, Financial literacy, Simulation, Middle school

DOI: $10.7176 / \mathrm{JEP} / 10-15-06$

Publication date:May $31^{\text {st }} 2019$

\section{Introduction}

Financial literacy is an important part of everyday life for individuals and families (Zucchi, 2018). Financial difficulties may occur from a lack of financial knowledge and relate to the health of the individuals and their families physically (Norvilitis, Szablicki, \& Wilson, 2003), economically (Alhabeeb, 1999), and psychologically (John, 1999). As cited by Jorgensen and Savla's (2010) extensive review of the literature, increased consumer debt (Lyons \& Hunt, 2003), a loss of savings and investments for retirement (Grable \& Joo, 1998), and unwise economic decisions (Allen, Edwards, Hayhoe, \& Leach, 2007) contribute to the financial burdens of families. Numerous surveys conducted on American youths' understanding of basic financial concepts consistently reveal that they lack basic knowledge of fiscal responsibility and do not possess adequate skills to be financially proficient in adulthood (American Savings Education Council, 2001; Americans for Consumer Education and Competition, 2001; Braunstein \& Welch, 2002; Charles Schwab, 2007; Jump\$tart, 1997, 2000, 2002, 2004, 2006, 2008; Yakoboski, 1999). For example, over $80 \%$ of graduating college seniors have credit card debt before they start working (Ramsey, 2018). Therefore, many young people are starting their lives as financial failures (Nerdwallet.com, 2011), and financial experts regard this situation as a ticking time bomb (Patoka, 2017).

The expectation, however, is that the students gain financial literacy skills from school or their parents, but, unfortunately this is not the case. Schools lack qualified teachers to teach financial literacy skills, and most parents are in debt themselves and cannot help their children when it comes to financial skills. Although 24 states mandate financial education (O'Brien, 2018), financial topics are not taught systematically as part of elementary, middle, or high school curricula. Examples of financial skills/topics include how to read a bank statement; how to maintain a simple budget; how to read and understand credit card, debit card, and loan offers; and how to build a positive credit history.

Though limited, there are computer applications (apps) and simulations used to impart financial skills. Among the popular financial literacy apps available on the market are: Mindblown Labs, LearnVest, Mint, Pocket Budget, and Pocketguard (Tabalba, 2017). While apps provide youth with financial calculation assistance and help them in maintaining budgets and tracking expenses, simulations involve activities that mimic real-world experiences and teach students skills such as decision-making and critical thinking (Jeffries, 2005).

There are many programs and curricula on financial literacy programs for youth that have positive outcomes. For example, studies of the National Endowment for Financial Education's (NEFE) High School Financial Planning Program (Boyce \& Danes, 1998; Danes \& Haberman, 2005, 2007) and the I Can Save program (Sherraden, Johnson, Guo, \& Elliott, 2009) indicate that participants increased their knowledge and skills. Large- 
scale evaluations of extension programs such as Money Talks in California (Varcoe \& Fitch, 2003; Varcoe, Martin, DeVitto, \& Go, 2005), Welcome to the Real World in Idaho (Spencer, Petty, Stimpson, Dees, \& Riley, 2003), Real Money, Real World in Ohio (Ferrari, Bateson, Hudson, Bridgeman \& Cochran, 2010) and 4-H Survivor Camp in Oregon (Smith, Cowan, \& Schreiber, 2008) have shown that simulations are effective in educating youth about financial topics.

Although financial content knowledge is not assessed in this paper, it is helpful to consider what type of information students come away with after they engage in simulation activities to assess whether to incorporate these types of programs within the middle school curriculum. The purpose of this article is to examine: 1) the experiences of middle school students who participated in the Reality Store $\mathbb{R}$; and 2) their level of career and the educational requirements necessary to achieve their desired life choices.

Literature Review

Because of the multifaceted nature of the Reality Store ${ }^{\circledR}$ involving simulations, financial literacy, and career awareness, this review of literature first considers the work of Kolb and the nature of experiential learning. Next, we examine a specific type of experiential activity namely, simulation. Finally, we describe the need for career awareness in middle school.

Kolb's Learning Theory

Kolb's (1984) theory of experiential learning is based on a four-stage learning cycle. Effective learning, according to Kolb, happens when a person progresses through a cycle of four stages: 1) having a concrete experience, followed by 2) observation of and reflection on that experience which leads to the 3) formation of abstract concepts (analysis) and 4) generalizations (conclusions), and which are then used to test hypothesis in future situations, resulting in new experiences (see Figure 1).

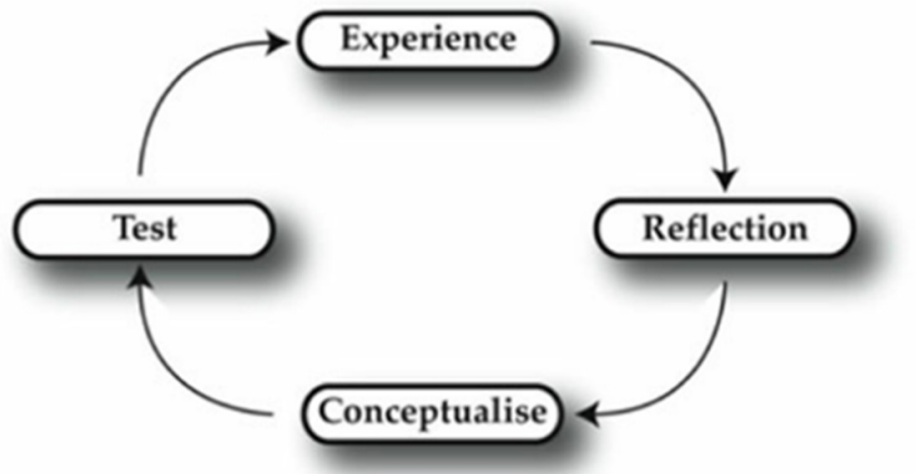

Figure 1: Kolb's Learning Theory

Kolb (1984) views learning as an integrated process with each stage being mutually supportive of and feeding into the next. It is possible to enter the cycle at any stage and follow it through its logical sequence. Kolb's learning styles help to frame experiential learning by drawing attention to the role of reflection. This is important when teaching using simulations.

Simulations

As an instructional technique, simulations "attempt to recreate certain aspects of reality for the purpose of gaining information, clarifying values...or developing a skill" (Cruz \& Patterson, 2005, p. 43). They provide students with hands-on activities that are as authentic as possible. Simulations come in many different forms depending on the subject matter, available resources, and time (Swinson, Clark, Ernst, \& Sutton, 2016). For instance, simulations can be in the form of role-play activities or software programs (e.g., used by trainee pilots). Technology plays an integral part in our lives and computer simulated-based software is becoming common for training purposes (Lateef, 2010). Simulations are a low risk instructional technique in that they allow students to make mistakes without catastrophic consequences (Gordon, Wilkerson, Shaffer, \& Armstrong, 2001; Kaufman \& Ireland, 2016). For instance, in the training of pilots, firefighters, medical doctors, and emergency responders, simulated training allows students to make errors that are neither costly nor fatal.

Simulations have been widely used in many other fields such as aviation, military (Lateef, 2010), nursing (Merriman, Stayt, \& Ricketts, 2014) and business (Emery, Borron, Cain, 2006); they have been applied to educational settings and were equally effective as traditional classroom methods of teaching (Lehtola, 2007). In addition to providing technical skills (Lachapelle, 2007), they can provide students with opportunities to practice decision-making through various real-life situational experiences (Kim, Park \& Shin, 2016). Furthermore, simulations have been known to increase students' interest in content areas and result in greater student retention of knowledge than conventional classroom instruction (Randel, Morris, Wetzel, \& Whitehill, 1992). With reference to financial literacy, researchers have concluded that teaching financial literacy in the abstract appears to be ineffective (Braunstein \& Welch, 2002), whereas highly interactive, reality-based courses in fiscal 
responsibility are effective in developing financially competent young adults (Varcoe, Martin, DeVitto, \& Go, 2002).

\section{Career Awareness}

In addition to financial literacy, career awareness is another important piece that students need to have for healthy participation in an economy (Calderon \& Hodges, 2016). Career awareness, where students are presented with opportunities and experiences to learn about different careers, is generally considered the foundation for career exploration (Alexander \& Miller, 2015). The University of California-Berkeley, defines career exploration as "a process of building self-awareness, learning about potential careers, and developing a plan for reaching future goals" (ACTE, 2018, p. 2). Individuals need to be aware of different careers before they can explore them. However, the educational level at which students are often introduced to career exploration varies. Experts believe that middle school is the ideal time when students can benefit from career exploration (ACT, 2018; Hughes \& Karp, 2004; Kerka, 2008). Furthermore, students in middle school are considered to be at a higher risk for disengaging from learning because of challenges in forming identity, coping with puberty and navigating new environments (Caskey \& Ankara, 2014). Introducing career exploration at this age capitalizes on youths' developing abilities to think abstractly and their preferences for teamwork and active learning through relevant real-life scenarios (ACT, 2018). These preferences make middle school a natural time for students to learn about careers and develop skills such as problem solving, critical thinking and teamwork through career exploration activities.

Throughout the duration of the Reality Store ${ }^{\circledR}$, students assume the role of a 25 -year-old adult who may or may not be the sole income provider for a family. They receive an occupation, monthly salary, and their family situation (number of children they are raising). Students learn to subtract savings, taxes, and health insurance amounts from their income. The amount of money left over is what they have to spend during the simulation activity. The simulation involves community volunteers who represent actual businesses in the community; they set up and staff booths representing real-life businesses. By visiting all appropriate booths, students spend their salaries on items typically found in a monthly budget, including housing, utilities, groceries, insurance, childcare, and transportation. Throughout the activity, students keep track of their finances and attempt to complete the simulation with a positive balance. During the post-simulation lesson, students reflect on their experience and what they learned by completing a self-assessment.

By examining student reflections, this study sought answers to the following questions:

1. How do middle school students value and process the experience of the Reality Store ${ }^{\circledR}$ ?

2. Did the simulation experience influence students' perceptions of consumer spending and saving?

3. To what extent were students aware of career options and the educational requirements of their chosen careers fields?

\section{Methods}

The Reality Store $\mathbb{R}$

The Reality Store ${ }^{\circledR}$ is part of the Women Helping Girls with Choices (Choices) program sponsored by Indiana Women's Education Foundation (IWEF, 2002) throughout the State of Indiana. The Choices program's goal is to provide opportunities to improve the economic self- sufficiency of women. It is the IWEF's contention, from evidence of state poverty data, that young women and men between the ages of 14 and 20 make critical decisions that affect the course of their whole lives, such as educational paths, career options, lifetime mates and family timing. They should make these decisions with knowledge and an awareness about the realities of and options for their futures.

The goals of the Reality Store ${ }^{\circledR}$ program are to:

1. Assist all students in applying basic skills in financial planning, goal setting, and decision-making, and career planning.

2. Clarify the need for students to examine their attitudes about their futures and their career expectations.

3. Motivate students to continue their education and make choices that have positive consequences (IWEF, 2002). There are three components of the Reality Store ${ }^{\circledR}$ :

1. Preparation. The day before the Reality Store $\AA$, teachers introduce the simulation and provide materials such as occupational information on monthly salaries, taxes, number of children, and marital status. Students choose their careers/jobs. Teachers randomly choose whether a student is single or married, has children, or has a working spouse.

2. The Reality Store ${ }^{\circledR}$ Event. Students visited 15 stations where they purchased supplies and services on the monthly salary (after subtracting taxes). Adult volunteers from the local community supervised the stations. Their role was to ensure that the student correctly filled in the transaction register. Each of the 15 stations offered students with choices based on their life circumstances. Before the end of the store, students were faced with one of life's unexpected events, such as an accident or winning a lottery. Table 1 lists the fifteen stations used by the Reality Store ${ }^{\circledR}$ activity. 
3. Evaluation and Discussion. The following day, students were asked to evaluate and discuss the program and describe what they learned from the simulation. Information gathered from the discussions during debriefing sessions were used to answer the research questions.

Table 1. The fifteen stations for the Reality Store ${ }^{\circledR}$

\begin{tabular}{ll}
\hline Banking & Housing \\
Utilities & Medical/Dental/Optical \\
Furniture & Legal \\
Groceries & Clothing \\
Child Care & Pet/Vet \\
Transportation & Charitable Contributions \\
Insurance & Entertainment/Travel \\
Life's Unexpected Events & \\
\hline
\end{tabular}

Although materials from the Indiana Women's Education Foundation provide suggestions and revisions on previous materials, additional work is required to update prices and services. Information to maintain current prices is available on the U.S. Department of Labor's website (https://www.bls.gov/ooh/)

Participants

Eighth grade students in a large Midwestern middle school participated in the Reality Store $\mathbb{R}(n=156)$ during their mathematics classes (90 minutes in length). Of these students, $48 \%$ were male and $52 \%$ female. Approximately $14 \%$ were identified as students with intellectual or developmental disabilities, with $90 \%$ of students eligible for the free or reduced lunch program. All students received financial literacy-type instruction before the simulation. The primary program and curriculum for this financial literacy class used in this middle school was Take Charge Today from the University of Arizona's School of Social and Behavioral Sciences. The Take Charge Today project is founded on the idea that a university-based financial education outreach program can strengthen and extend the ability of schools and community organizations to improve the personal financial capabilities of students (https://takechargetoday.arizona.edu/).

Data Analysis

This study was descriptive in design and used quantitative and qualitative data. A self- assessment was completed the day after the Reality Store ${ }^{\circledR}$ experience; it evaluated what students felt they became more aware of in terms of cost of items, the importance of an education/career presented, and the significance of what they learned. The assessment used fixed-response questions.

Once the self-assessments were collected all responses were entered using EXCEL for greater ease in presenting data. The responses were summarized with descriptive statistics. Qualitative data from discussions during the debriefing sessions were recorded and analyzed using open coding to identify themes. Data analysis began with reading through the data multiple times and identifying initial themes. Coding procedures from grounded theory were utilized (Strauss \& Corbin, 1998). The authors began with open coding, a process through which data "are broken down into discrete parts, closely examined, and compared for similarities and differences" (Strauss \& Corbin, 1998, p. 102). During the open coding stage, data were reviewed to understand what students were expressing in their responses. The second step in the coding process was to use axial coding, for reassembling the data to develop connections and categories within the data across participant. This process supports research triangulation of data, a method of increasing trustworthiness (Lincoln \& Guba, 1985).

\section{Findings}

Value of Experience

Based on the self-assessment and data from debriefing sessions, students overwhelmingly felt that the Reality Store ${ }^{\circledR}$ was worthwhile $(\mathrm{n}=145,93 \%)$ and enjoyed the experience $(\mathrm{n}=142,91 \%)$. The answers varied when students described what they found valuable through the simulation, with only $3 \%$ of students believing they did not learn anything new (see Table 2). 
Table 2. Ranking of what students learned from the Reality Store ${ }^{\circledR}$

\begin{tabular}{lc}
\hline What Students Learned from the Experience & Percent of Students \\
\hline Awareness of the cost of items and of having children & $32 \%$ \\
Save your money and don't overspend & $17 \%$ \\
A window into what it will be like as an adult & $15 \%$ \\
The value of being prepared -jobs & $7 \%$ \\
The difference between wants and needs & $6 \%$ \\
The cost of a single parent family & $6 \%$ \\
Budgeting & $5 \%$ \\
Life is Hard/Manage Your Money & $5 \%$ \\
Nothing_I already knew this & $3 \%$ \\
Many things & $1 \%$ \\
When you borrow money...you pay more back & $1 \%$ \\
Go to college and get more money & $1 \%$ \\
Parent's sacrifices & $1 \%$
\end{tabular}

Among some of the more interesting comments were "I learned that being an adult is hard;" and "I really need to get a better job and wait to have children - they (children) are really expensive!" Overall, students' responds indicated a lack of awareness on the cost of raising children.

Changes in Perspectives and Career Awareness

A question on the self-assessment asked, "After participating in the Reality Store ${ }^{\circledR}$, what would you do differently, if anything?" Approximately $68 \%$ of students who were assigned to have children and were required to pay for childcare commented that they would not have children so early in their lives. Before the simulation, students were randomly divided between two groups, those having "children" and those "without children." Those having children were randomly assigned one, two, or three children. Table 3 shows specific changes the students would make in life to have the lifestyle they desired.

Table 3. What would you change in your "Life"?

$\begin{array}{lc}\text { Students Randomly Assigned } & \text { Students Randomly Assigned } \\ \text { Children }(n=77) & \text { No Children }(n=79)\end{array}$

Wait to have children $(68 \%)$

Choose another career $(12 \%)$

Save more money $(7 \%)$

Nothing $(2 \%)$
Choose another career $(53 \%)$

Save more money $(26 \%)$

Nothing, I had some money left (11\%)

Not to spend so much on anything $(10 \%)$

For those students who were not assigned children, the majority wanted to change their careers. Even without a child, one student commented during the debriefing, "I just can't make it on my own" (She chose to be a beautician). Table 4 lists students' top 11 initial choices. The students who wanted to change their careers/jobs had jobs that required high school, technical, or associate degrees $(n=68)$. Students did not realize the amount of education that was required for their particular career/job choice. For example, when the researchers suggested the number of years of education required to become a surgeon, seven of the students who selected that career, expressed surprise. One student commented, "I am not going to be in school that long. No way." The most surprising finding was the lack of knowledge about college and career readiness that is required for their choice of careers and jobs. A small minority of students (those in honors algebra, $n=24$ ) did understand the number of years and coursework that was required.

Table 4. Students career choices

\begin{tabular}{|c|c|c|}
\hline Animal Related Careers $(n=20)$ & Careers $\quad(n=17)$ & Doctor $(n=16)$ \\
\hline Lawyer $(n=14)$ & Musician-Rock Band ( $\mathrm{n}=9$ ) & Construction $(n=8)$ \\
\hline Armed Forces $(n=8)$ & Writers $(n=5)$ & Hair \& Nails $(n=5)$ \\
\hline Models $(n=5)$ & Psychology $(n=5)$ & \\
\hline
\end{tabular}

How Students Processed the Reality Store ${ }^{\circledR}$

Student responses to the question, "What aspect of The Reality Store ${ }^{\circledR}$ did you like most?" ranged in terms of their ability to analyze the process. For example, "I enjoyed walking and being with friends," and "This was fun. It got us out of our desks." Other students who were able to analyze the situation in terms of broader goals: "I am more aware of what it means to be an adult and to be independent." Four themes emerged from the responses to what students enjoyed:

1. Friends $(n=17)$. Students appreciated the fact that they were able to negotiate their transactions with friends. "Being able to shop with my friends and walking around reminded me of going to the mall."

2. Freedom to Make Choices $(n=32)$. The ability to make choices was critical for many students. "I liked feeling like I was making choices like an adult." 
3. Cars and Houses $(n=65)$. Adult supervisors at each of these stations not only sold houses and cars, they asked realistic questions of students. Again, freedom to choose two of life's most significant decisions was mentioned often. "I loved buying my own home and car."

4. Realization of Expenses ( $\mathrm{n}=42)$. "If this is what real life is like, I am in big trouble."

\section{Discussion and Recommendations}

Students valued the Reality Store ${ }^{\circledR}$. Most students agreed or strongly agreed with statements about the value of participating in the simulation. They were most positive about the experiential nature of the program. Most students $(89 \%)$ would tell the school administrators to continue with the activity. One teacher expressed the feelings of others, "No matter how much I tried, I could never teach them the value of money and savings like the Reality Store ${ }^{\circledR}$ did." Such an acknowledgement from teachers on the effectiveness of a simulation underscores its value on imparting financial literacy skills. Furthermore, the students particularly enjoyed the hands-on activities and the use of calculators. As supported in the literature, simulation activities generate much interest and create interactive activities for the students. Therefore, in the absence of qualified teachers to teach financial literacy, such simulation activities can effectively complement some concepts of consumer and financial literacy.

According to the Indiana Women's Education Foundation, which created the Reality Store ${ }^{\circledR}$, one of the primary goals of the program was to have young students "walk in the shoes of older adults" and to realize how difficult it can be if young adults become single parents of young children. Overwhelmingly, students cited having children as the source of their financial difficulties. No doubt, that many parents would welcome such a realization by their children, and would encourage such activities as another way to teach students life lessons. Furthermore, several students noted how complex adult life can be and that made the simulation a positive learning experience. The 15 different stations provided a realistic picture of current and regional conditions, making the learning experiences authentic. According to the founder of the Junior Achievement Bureau "Habits of life are formed in youth... What we need in this country now...is to teach growing generations to realize that thrift and economy, coupled with industry, are necessary now as they were in past generations" (1919, as quoted in Francomano, Lavitt, $\&$ Lavitt, 1988). These words echo the responses of teachers and students participating in the Reality Store ${ }^{\circledR}$. The eighth grade mathematics classes became the target audience for the Reality Store ${ }^{\circledR}$ for many reasons. First, students schedule high school courses during their eighth grade and can choose classes that may support their future careers. Second, eighth graders are capable of understanding the mathematics behind the Reality Store ${ }^{\circ}$, and third, many youths are a few years away from part-time jobs and more responsibilities.

Another finding from the Reality Store ${ }^{\circledR}$ simulation was the lack of students' awareness of educational requirements for professions. According to teachers, this finding was not surprising considering the possible lack of exposure to careers at this age. Although students can obtain information on careers from the media, peers, and parents, according to Hendler-Grunt (2018) that is often not the case. Such a lack of exposure to careers has prompted many states to offer career awareness as part of the middle school curriculum. For instance, the state of Ohio offers career awareness (elementary grades), career exploration (middle school) and career planning (high school) programs as part of career and technical education at the middle school level. For information on the career connections framework, see Ohio Department of Education (2017).

Based upon our findings of students' perceptions of the Reality Store ${ }^{\circledR}$, this study makes the following recommendations:

1. Simulations are a useful tool for teaching financial literacy concepts. However, where such simulation activities are used, the experiences should include realistic scenarios, clear instructions for participants with a preview of what to expect, and a thorough debriefing where students discuss their experiences and what they learned.

2. The use of professionals and community members to assist with the simulation activities adds value to creating realistic situations. Some members from the community may volunteer for such activities.

3. There is need to teach financial literacy, career awareness, and career exploration in middle school. Resources permitting, this could be done through apps, financial experts or simulations.

4. Resources similar to the Reality Store ${ }^{\circledR}$ are available online and through extension services, free of charge or for a small fee. For materials on the Reality Store ${ }^{\circledR}$, visit: http://www.inwomeneducation.org/

This paper analyzed middle school students' experiences after participating in a financial literacy simulation. Future studies could explore the long-term effects of simulations as well as the efficacy of online simulations.

\section{References}

Alexander, K. L., \& Miller, C. L. (2015). Grow your own tree: Tools for career readiness, exploration and evaluation. Techniques: Connecting Education \& Careers, 90(6), 8-9.

Alhabeeb, M. J. (1999). Allowances and the economic socialization of children. Association for Financial Counselling and Planning Education, 10(2), 1- 9.

Allen, M. W., Edwards, R., Hayhoe, C. R., \& Leach, L. (2007). Imagined interaction, attitudes towards money and 
credit, and family coalitions. Journal of Family and Economic Issues, 28, 3-22.

American Savings Education Council. (ASEC). (2001). Parents, youth and money 2001: Executive summary. Retrieved from the Employee Benefits Research Institute website: http://www.ebri.org/surveys/index.cfm?fa=pym

Americans for Consumer Education and Competition. (2001). Nation's high school seniors fail at finance fundamentals. Retrieved from http://www.todaysmoneymatters.org/family/moneyskillsreport/

Association of Career and Technical Education. (ACTE). (2018). Career exploration in middle school: Setting students on the path to success. Retrieved from https://www.acteonline.org/wpcontent/uploads/2018/02/ACTE CC Paper FINAL.pdf

Boyce, L., \& Danes, S.M. (1998). Evaluation of the NEFE High School Financial Planning Program ${ }^{\circledR}$ 1997-1998. Retrieved from the National Endowment for Financial Education website: http://hsfpp.nefe.org/loadFile.cfm?contentid=646

Braunstein, S., \& Welch, C. (2002). Financial literacy: An overview of practice, research, and policy. Federal Reserve Bulletin (November), 445-457. Retrieved from http://www.federalreserve.gov/pubs/bulletin/2002/1102lead.pdf

Calderon, V.J., \& Hodges, T. (2016, April 7). Career, Financial Literacy Skills Key to Students' Futures. Retrieved from https://news.gallup.com/opinion/gallup/190544/career-financial- literacy-skills-key-studentsfutures.aspx

Caskey, M., \& Ankara, Jr., V. A. (2014). Developmental Characteristics of Young Adolescents: Research Summary. Westerville, $\mathrm{OH}$ : Association for Middle Level Education.

Charles Schwab, Inc. (2007). Charles Schwab Teens \& Money 2007 Survey Findings: Insights into money attitudes, behaviors, and concerns of teens. Retrieved from: http://charlesschwabfoundation.com/community/financial-literacy/teens-and-money.html

Cruz, B. C., \& Patterson, J. M. (2005). Cross-cultural simulations in teacher education: Developing empathy and understanding. Multicultural Perspectives, 7(2), 40-47.

Danes, S.M., \& Haberman, H. (2005). Evaluation of the NEFE High School Financial Planning Program 20032004. Retrieved from the High School Financial Planning Program website: http://hsfpp.nefe.org/loadFile.cfm?contentid=273

Danes, S.M., \& Haberman, H.R. (2007). Teen financial knowledge, self-efficacy, and behavior: A gendered view. Financial Counselling and Planning, 18(2), 48-60.

Emery, T., Borron, A., \& Cain, S. (2006). Ready business: Preparing a disaster business plan. Retrieved August 1, 2006, from http://eden.lsu.edu/LearningOps/ReadyBusiness/default.aspx

Ferrari, T.M., Bateson, L., Hudson, N., Bridgeman, B., \& Cochran, G. (2010). Getting real results with Ohio State University Extension's Real Money. Real World. Program. Journal of Research Development, 2(5), 18-32.

Francomano, J., Lavitt, W., \& Lavitt, D. (1988). Junior Achievement: A history. Colorado Springs, Col.: Junior Achievement Inc.

Gordon, J. A., Wilkerson, W. M., Shaffer, D. W., \& Armstrong, E. G. (2001). Practicing medicine without risk: Students and educators' responses to high fidelity situations. Academic Medicine, 76(5), 469-472.

Grable, J. E., \& Joo, S. (1998). Does financial education affect knowledge, attitudes, and behavior? An empirical analysis. Personal Finances and Worker Productivity, 2(2), 213-220.

Hendler-Grunt, B. (2018, Feb 15). Is Anyone Listening? The Top Parental Career Advice Ignored By Students. Retrieved from http://www.nextgreatstep.com/is-anyone-listening- the-top-parental-career-advice-ignoredby-students-graduate-job-college-interview-res

Hughes, K. \& Karp, M. (2004). School-Based Career Development: A Synthesis of the Literature. Teachers College, Columbia $\quad$ University. $\quad$ Retrieved from https://www.tc.columbia.edu/iee/PAPERS/CareerDevelopment02_04.pdf

Indiana Women's Education Foundation. (2002). Women Helping Girls With Choices. Retrieved from http://www.inwomeneducation.org/

Jeffries, P.R. (2005). A framework for designing, implementing, and evaluating: Simulations used as teaching strategies in nursing. Nursing Education Perspectives, 26(2), 96-103.

John, D. R. (1999). Consumer socialization of children: A retrospective look at twenty-five years of research. The Journal of Consumer Research, 26(3), 183 - 213.

Jorgensen, B.L., \& Savla, J. (2010). Financial literacy of young adults: The importance of parental socialization. Family Relations, 59, 465-478.

Jump\$tart Coalition. (1997). High school seniors lack financial smarts shows survey [Press Release]. Retrieved from: http://www.jumpstart.org/upload/news.cfm?recordid=37

Jump\$tart Coalition. (2000). Financial literacy declining among 12th graders: Coalition urges states to include personal finance in curriculum standards [Press Release]. Retrieved from: http://www.jumpstart.org/upload/news.cfm?recordid=60 
Jump\$tart Coalition. (2002). From bad to worse: Financial literacy drops further among 12th graders [Press Release]. Retrieved from: http://www.jumpstart.org/upload/news.cfm?recordid=99

Jump\$tart Coalition. (2004). Financial literacy improves among nation's high school students [Press Release]. Retrieved from: http://www.jumpstart.org/news.cfm

Jump\$tart Coalition. (2006). 2006 Survey: Financial literacy shows slight improvement among nation's high school students [Press Release]. Retrieved from: http://www.jumpstart.org/news.cfm

Jump\$tart Coalition. (2008). Financial literacy still declining among high school seniors, Jump\$tart Coalition 2008 survey shows [Press Release]. Retrieved from: http://www.jumpstart.org/news.cfm

Kaufman, D., \& Ireland, A. (2016). Enhancing teacher education with simulations. TechTrends, 60(3), 260-267.

Kerka, S. (2000). Middle School Career Education and Development. Clearinghouse on Adult, Career, and Vocational Education. Retrieved from http://www.calpro- online.org/eric/docs/pab00018.pdf

Kim, J., Park, J.H., \& Shin, S. (2016, May 23). Effectiveness of simulation-based nursing education depending on fidelity: A meta-analysis. BMC Medical Education. 16: 152. doi: 10.1186/s12909-016-0672-7

Kolb, D.A. (1984). Experiential learning: experience as the source of learning and development. Englewood Cliffs, NJ: Prentice-Hall.

Lachapelle, K. (2007). Teaching technical skills using medical simulation: A new frontier. McGill Journal of Medicine, 10(2), 149-151.

Lateef, J. (2010). Simulation-based learning: Just like the real thing. Journal of Emergencies, Trauma, and Shock. 3(4), 348-352. doi:10.4103/0974-2700.70743

Lincoln, Y. S., \& Guba, E. G. (1985). Naturalistic inquiry (7th Ed.). Newbury Park, CA: Sage Publications.

Lyons, A. C., \& Hunt, J. L. (2003). The credit practices and financial education needs of community college students. Association for Financial Counselling and Planning Education, 14(1), 63 - 74.

Merriman, C.D., Stayt, L.C., \& Ricketts, B. (2014). Comparing the effectiveness of clinical simulation versus didactic methods to teach undergraduate adult nursing students to recognize and assess the deteriorating patient. Clinical Simulation in Nursing, 10(3), e119-e127

Nerdwallet.com (2011, February 15). Are Young Adults Being Set on the Road to Financial Failure? Retrieved from http://blog.quizzle.com/2011/02/are-young-adults-being-set-on- the-road-to-financial-failure/

Norvilitis, J. M., Szablicki, P. B., \& Wilson, S. D. (2003). Factors influencing levels of credit- card debt in college students. Journal of Applied Social Psychology, 33, 935 - 947.

O'Brien, S. (2018, April 16). These 10 states do the best job of teaching kids about money. Retrieved from https://www.cnbc.com/2018/04/16/these-10-states-do-the-best-job-of-teaching-kids-about-money.html

Ohio Department of Education. (2017). Career Connections Framework. Retrieved from http://education.ohio.gov/Topics/Career-Tech/Career-Connections/Career-Connections- Framework.

Patoka, J. (2017, October 31). The ticking time Bomb of Student Loan Debt in the US. Retrieved from http://thefinancegenie.com/personalfinance/education/ticking-time-bomb-student- loan-debt-u-s

Ramsey, D. (2018). The Truth about Teens and Credit Cards. Retrieved from https://www.daveramsey.com/blog/the-truth-about-teens-and-credit-cards

Randel, J., Morris, B., Wetzel, C., \& Whitehill, B. (1992). The effectiveness of games for educational purposes: A review of recent research. Simulation and Gaming, 23, 261-276. http;//dx.doi.org/10.1177/104687819223300

Sherraden, M., Johnson, L., Guo, B., \& Elliott, W. (2009). Financial capability in children: Effects of participation in a school-based financial education program (Working Paper). Retrieved from the Washington University in St. Louis Center for Social Development website: http://csd.wustl.edu/Publications/Documents/WP0916.pdf

Smith, C., Cowan, J., \& Schreiber, D. (2008). 4-H "survivor" camp: A real-life experience in living on your own. Journal of Youth Development, 3(2), Article 080302PA002. Retrieved from: http://web.memberclicks.com/mc/page.do?sitePageId=100185\&orgId=nae4a

Spencer, M., Petty, B., Stimpson, J., Dees, L., \& Riley, L. (2003). "Welcome to the Real World" positively affects youth financial skills, knowledge, and attitudes. Journal of Extension, 41(2), Article 2TOT3. Retrieved from: http://www.joe.org/joe/2003april/tt3.php

Strauss, A., \& Corbin, J. (1998). Basics of qualitative research: Techniques and procedures for developing grounded theory (2nd Ed.). CA: Sage.

Swinson, R., Clark, A. A., Ernst, J. J., \& Sutton, K. K. (2016). Design, test, redesign: Simulation in technology, engineering, and design education classrooms. Technology \& Engineering Teacher, 75(7), 8-12.

Tabalba, M. (2017, October 13). Smartphone apps can help students conquer financial literacy, maintain a budget and track bills. Retrieved from https://blog.nextstepu.com/5-best-financial-literacy-apps-for-collegestudents/

Varcoe, K.P., \& Fitch, P.R. (2003). Money talks - a program to improve financial literacy of teens. International Journal of Consumer Studies, 27(3), 225-226. 
Varcoe, K.P., Martin, A., DeVitto, Z., \& Go, C. (2005). Using a financial education curriculum for teens. Financial Counseling and Planning, 16(1), 63-71.

Yakoboski, P. (1999). Lessons from the 1999 youth and money survey. ERBI Notes, 20(8), 5-8. Retrieved from Employee Benefits Research Institute website: http://www.ebri.org/pdf/notespdf/0899notes.pdf

Zucchi, K (2018). Why financial literacy is so important. Retrieved from https://www.investopedia.com/articles/investing/100615/why-financial-literacy-and-education-soimportant.asp 